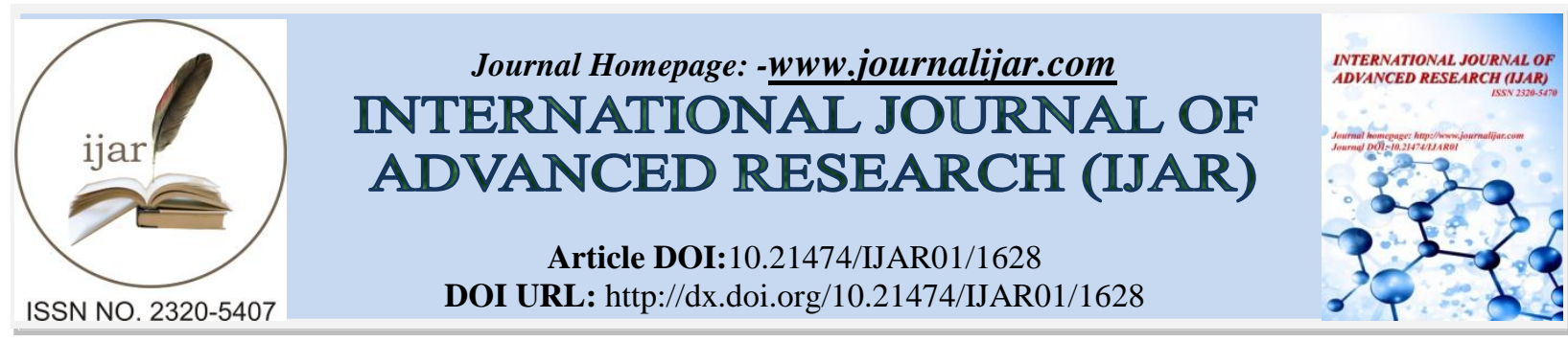

RESEARCH ARTICLE

\title{
DILEMMA, DISPLACEMENT AND DISLOCATION IN THE NAMESAKE.
}

\section{Dr.Syed Ahmad RazaAbidi ${ }^{1}$ and VeronicaMondal ${ }^{2}$.}

1. Assistant Professor of English, Sri SatyaSai University of Technology and Medical Sciences, Sehore, Madhya Pradesh.

2. Research Scholar, Department of English, Sri SatyaSai University of Technology and Medical Sciences, Sehore, Madhya Pradesh.

\section{Manuscript Info} -......................... Manuscript History

Received: 12 July 2016

Final Accepted: 19 August 2016

Published: September 2016

Key words:-

Diaspora, Displacement, Immigrant,

Alienation, Dislocation

\section{Abstract}

JhumpaLahiri mainly deals with the ordinary life of immigrants settled abroad. Her novel The Namesake speaks about the relationship and rituals of family and country in a simple yet elegant and profoundly controlled manner.It also deals with the issues of cultural and racial - discrimination and the problems of inter-racial relationship. The story of the novel is woven around an immigrant Indian Bengali family living in United States of America. The attempt of Ashoke and Ashima Ganguli to adjust in the new ambiance and the feeling of frustration and displacement experienced by their son Gogol forms the theme of the novel.JhumpaLahiri shows that though diasporas struggle to conserve their customs and ethnicity, yet they gradually imbibe the social and cultural way of life of the host country.

Copy Right, IJAR, 2016,. All rights reserved.

\section{Introduction:-}

JhumpaLahiri'sThe Namesake (2003) is a novel about Asian, particularly Indian immigrants in America. It deals with the diasporic experiences of these immigrants and presents in detail the problems of adjustment and non-belonging, identity crisis and rootlessness. It also deals with the issues of cultural and racial- discrimination and the problems of inter-racial relationship.On the surface level The Namesake is a simple story of a family moving to America in search of a prospective livelihood. AshokeGanguli is an electrical engineer working towards his doctorate in MIT, Massachusetts. One summer he comes to India and returns with his new bride Ashima. For the next thirty years, the novel follows the lives of this young couple as they try to find their foothold in a foreign land. As they settle down with their two children, America almost becomes their home. A deeper look at the characters reveals a discontentment as they try to assimilate themselves. As first generation immigrants, Ashoke and Ashima look to India for bonding. Their children, Gogol and Sonia, born and brought up in America, cannot relate to this bonding. The central characters, especially Ashima and her son Gogol are like waves battling to reach their home but always returning discontent. As the story progresses, it can be seen that the characters are sucked into the cultural vortex. Trying to find a balance between their inherent Indian culture and the adoptive American culture, they turn out to represent fine examples of multiculturalism.

Corresponding Author:-Dr.Syed Ahmad RazaAbidi.

Address:-Assistant Professor of English Sri SatyaSai University of Technology and Medical sciences,Sehore, Madhya Pradesh. 
At the heart, The Namesake is about parents and children and at the most basic level, this is a story of a family that is coming to grip with who they are and where they are under what circumstances. Vijay Mishra writes, "This novel, too, is about movement and settlement in a new land; it is about a fragmented society lost in nostalgia for a lost world and about children born elsewhere who cannot totally connect with the unchanging world views of their parents"193).Lahiri feels that it is not only the Indian migrants who feel dislocated in other cultures and face intellectual impasse, immigrants from any culture feel the same in any dominant culture. Lahiri sometimes perceives diasporas and their descendants as the marginalized mimics of centralized Americans. These issues have also been discussed in the light of diasporicperspective. John McLeod observes that in Post-colonial literature the issue of nation and nationalism is of vital importance. During the several struggles against colonial rule in the 20th century the myth of the nation has proved highly potent and productive. In the modern world the nation has become one of the most important modes of social and political organization. As Ernest Gellner argues, "Nations are not inscribed into the nature of things. Nations, like buildings, are planned by people and built upon particular foundations which also mean that, like buildings, they can both rise and fall"(68).So, the nation is basically an idea. ChrissBerry says: "It is a discordant and dynamic conjecture, constituted when different trajectories meet, intersect overlay, fragment and produce a hybrid forms within a certain geographic space" (4).In a similar vein Timothy Brennan claims "The nation refers, both to the modern nation-state and to something more ancient and nebulous - the nation, a local community, domicile, family, condition of belonging" (46).

The sense of mutual, national belonging is manufactured by the performance of various narratives, rituals and symbols, which stimulate an individual's sense of being a member of a select group.The nation depends upon the invention of national traditions which are made manifest through the repetition of specific symbols or icons. The performance of national traditions keep in place an important sense of continuity between the nation's present and its past, and helps concoct the unique sense of the shared history and common origins of its people.Nations often traffic in highly revered symbols that help forge a sense of its particular, idiosyncratic identity in which the nation's people emotionally invest. Nation promises structure, shelter and sequence for individuals, connecting a deep horizontal comradeship, which unites the many into one imagined community through the function of specific forms of narrative. Individuals as well as groups of people belonging to particular nation-communities in diasporic situations oscillate between two identities, two culture-value systems and even two mind-sets - one belonging to the nation and the community they are migrating from and the other the nation and the community they are migrating into. K.T. Sunita points out, "Indian expatriate writers do not write from the position of a distant foreign community, such as the exiled Black or West Indian novelist, but their writing reflects the perspective of someone caught between two cultures"(82).

Loss, alienation, rootlessness and dislocation are experienced by every expatriate at some stage or the other. Most of these writings seem almost autobiographical to the extent that they reflect the experiences of the diasporic community to which the writers belong. In JhumpaLahiri's case, she is a second generation immigrant and is hence better able to understand and replicate the sandwich culture in her novel. As the daughter of an educated parent, Lahiri is able to focus in this novel only on that class of people to which she belongs. She sets her stories in two countries-India and America. As an Indian living in the United States of America, she seems to be more at home with the situation in America.Lahiri mainly deals with the ordinary life of immigrants settled abroad. The Namesake speaks about the relationship and rituals of family and country in a simple yet elegant and profoundly controlled manner. The story of the novel is woven around an immigrant Indian Bengali family living in America. The attempt of Ashok and AshimaGanguli to adjust in the new ambiance and the feeling of frustration and displacement experienced by their son Gogol forms the theme of the novel.

The novel opens in the year 1968; Ashima is expecting her first child. To satisfy her hunger pangs, she has a mixture of puffed rice, peanuts, chopped onions and green chilies and lemon juice. As she munches on it, she feels something is amiss in the concoction. Somehow she will never get it right, the kind that is sold on the streets of Calcutta. Soon she goes into labour and her husband rushes her to the hospital. Her thoughts rush back to her home town, where she would have been surrounded by her family and relatives. Here, she is all by herself, probably the only Indian in the hospital. More than the pain induced by labour it is this loneliness that tugs at the strings of her 
heart."...she is terrified to raise a child in a country where she is related to no one, where she knows so little..." (The Namesake 6). Later the Bengalis whom the Gangulis have befriended come to visit the baby boy. However, for Ashima, no one can take the place of the family members. She looks at her son and thinks "She has never known of a person entering into the world so alone, so deprived" (The Namesake 25). The three days that she stays at the hospital she is given all the instructions about baby care. On the fourth day when she is to be discharged, the doctor asks for the baby's name to be written on the birth certificate. Ashoke and Ashima are waiting for a letter from India that will have the baby's name in it. Ashima's great grandmother is given this duty. The letter never arrives and the Gangulis encounter their first cultural problem. In Americapeople have names ready as babies cannot be released from the hospital without a birth certificate. The doctor gives them suggestions as to how it is their tradition to name the child after one of their ancestors. The Gangulis are shocked to know this as their Bengali custom is completely different. The naming ceremony is an elaborate procedure in India. And the Bengalis have the tradition of giving a person two names; a pet name, a Daknam,called by family, relatives and close friends. Then there is a good name, a Bhalonam, to be called by the world outside. Ashoke decides to name his son Gogol after the Russian author Nikolai Gogol. Years ago, Ashoke was in a terrible train accident and he happened to be reading a book by this author, and incidentally the book saved his life. Ashima also is happy with the name and they both decide that they can give him a good name when he starts school. Soon life with the baby takes a toll on Ashima as she has no one to look up to. Very often she cries and keeps reading her parents' letters again and again. She also has a few Bengali magazines that she clings on to, the only remnants of her culture in this foreign land. She tells her husband, “... I don't want to raise Gogol alone in this country. It's not right. I want to go back" (The Namesake 33). Despite her protests nothing really changes and Ashima soon gets adjusted with her new routine.

Delineating succinctly the everyday life of these characters, she nonetheless plumbs the innermost recesses of Gogol and AshimaGanguli's mind. The novel begins with the birth of Ganguli's first child, a son named Gogol after the $19^{\text {th }}$ century Russian writer. This novel charters the full career of this family in America till the demise of Ashoke brings in a drastic change in the emotional lives of Gogol, Ashima and Sonia. Gogol, who finds himself itching to cast off his awkward name, rechristens himself as Nikhil. As Nikhil, he studies architecture and begins his career in New York which brings him into contact with his girlfriend Maxine Ratliff. Later on he meets MoushumiMazoomdar, the woman whom Gogol's mother desperately wants him to marry and who after the marriage deceives him by continuing her affair with her ex-lover Dmitri. The novel winds up with the loneliness of Gogol and his mother Ashima and their seeking for refuge in their Bengali roots. Here, Lahiri's spotlight is on the concealed deposit of the consciousness and the internal confusion of the characters who find themselves, ensnared between the two cultures. In The Namesake, as in Lahiri's life the concept of diaspora has to be specifically understood as a single educated male deciding to leave his native country and to moving to another more developed western country for economic gain: from the moment Ashok decides to settle in America, Lahiri provides the reader with a picture of the life of the expatriate.

Lahiri shows that though diasporas struggle to conserve their customs and ethnicity, yet they gradually imbibe the social and cultural way of life of the host country. Though, earlier Ashoke did not like the commemoration of Christmas and Thanksgiving but as Gogol recalls, "it was for him, for Sonia, that her parents had gone to the trouble of learning these customs" (The Namesake 286). Their own children are more Americanized than what they want them to be. Though they are made to participate in pujas and other religious ceremonies, Gogol and Sonia, like the children of other Bengali families, relish American food more than the Bengali dishes. These parents though initially find it difficult to partake with their children's wishes, have to integrate the American way of living into their lives for the sake of their children, $\backslash$ “The Ganguli's:Learn to roast turkeys . . . at Thanksgiving, to nail a wreathe to their door in December, to wrap woolen scarves around snowman, to color boiled eggs violet and pink at Easter for the sake of Gogol and Sonia.... they celebrate progressively increasing fanfare, the birth of Christ, an event the children look forward to for more than the worship of Durga and Saraswati" (The Namesake 64).

The psychological movement from one state of mind to another causes dilemma, nostalgia, sense of displacement and loss. It can be said Lahiri strives to reconcile the odds between two diametrically opposing cultures and hence her novel proves itself a great saga of diasporic experiences as far as the theme is concerned.To expiate upon the postcolonial writing is to take into the perspective those 
discursive practices which determine a migrant's identity and shape it. In a country coming to terms with globalization and seeking to define a presence beyond its border, the diasporic identities become an obsessive concern. The Indian diaspora is today an incontestable fact of world ethnicity. They have had, perhaps most visibly through cultural artifacts, something of a global presence over the last few decades. Post-colonial discourse of this diasporic experience ought to discuss their marginality, identity search and also the ideological impact of the existing societies on their personal and social ideas and relationship.Being alone in an alien land, Gogol continues to struggle to find meaning and faith in the land which is now his. But all second generation immigrants do not react like Gogol. As we see in the case of his sister Sonia. Though in her teens Sonia is completely Americanized in spite of her parents objections, but after her father's death, she provides complete emotional support to her mother and with her consent, plans to settle in life after her marriage with Ben, a half Chinese raised in Newton. Moushumi a second generation Indian Bengali who earlier had relations with men in Paris, breaks her marital ties with Gogol and decides to leave with Dmitri, a German as she doesn't want to remain bound to her cultural roots.

In this way the novel presents Gogol, Sonia and Moushumi as emblematic of fissured identities generated by the colonial dislocations of their parents. It portrays how a split, ambivalent, hybrid subject is able to exist anywhere in this colonial world. The novel talks about those young men who want to get rid of their inheritance, their heritage and happen to find it later on. This is the story of immigrant children who inevitably grow with confused identities. Inter-racial relationship is another important issue in the novel which shows the inequality in power relations. Europeans have colonized India for centuries and exploited it. Indians living in white societies are still treated as subjects by the natives. The ruling class achieves domination by creating subjects who willingly submits to being ruled. The Namesake depicts how subjectivities are ideologically constructed. Being rooted in the 'third world' countries which have a common history of colonial exploitation, Indians living in white societies share their cultural roots and opposition to the legacy of colonial domination.

HomiBhabha, in his essay "Of Mimicry and Man: The Ambivalence of colonial Discourse" says that the colonial encounter between the white presence and its black semblance gives rise to the question of the ambivalence of mimicry. Bhabha describes mimicry as "One of the most elusive and effective strategies of colonial power and knowledge". (85) The ideological ambivalence in Lahiri's novel supports Bhabha's point. The Namesake depicts how Gogol, his sister Sonia, his wife Moushumi are created as the marginalized mimics of centralized Americans. In their effort to break away with Indian values, they have lost their own identities. The Americanized Indian offspring's adopt a very different lifestyle which is contradictory to that of their Indian parents'. The American ideology leaves a very deep impact upon the lives of Gogol, Sonia, and Moushumi and they became indifferent towards the moral values which their parents adheredto. When Gogol and Sonia go to India, they are teased about their American accents whereas in America they are constantly reminded of their questionable identity.

On Gogol's birthday which he celebrates with his girl friend Maxine's family, Pamela questions his Indianness specially pertaining to his name which is neither Indian nor American but a mimic of the Russian writer Nikolai Nasilievich Gogol. When he comes to know the significance of his name, it is too late. By that time he creates an alternative identity to disguise his name which had always troubled him like the scratchy tag of a shirt he has been forced permanently to wear. Bhabha argues: "....as a consequence in colonialist representations the colonized subject is always in motion, sliding ambivalently between the polarities of similarity and difference, he or she simply will not stand still"(53).Moushumi, Gogol's wife goes a step further. When she finds herself mimicking American values she finds an escape-hatch in the form of the French language;

Immersing herself in a third language, a third culture, had been her refuge - she approached French, unlike things American or Indian, without guilt, or misgiving, or expectation of any kind. It was easier to turn her back on the two countries that could claim her in favour of one that had no claim whatsoever. (The Namesake 214) 


\section{Conclusion:-}

On the basis of the above interpretations, it can be said that JhumpaLahiri in the novel The Namesake struggles with characters that are trapped wandering between two worlds, two personalities. The confrontation between the East and the West, the strange love-hate relationship that springs up between the two, the cultural alienation and loss of identity faced by the expatriates and immigrants are some of the aspects that are presented with deep insight in this novel. JhumpaLahiri handles the complexities of the immigrant experiences in their various nuances in a language that is very simple and lucid.JhumpaLahiri'sThe Namesake is undoubtedly written for all those people who are the descendants of the diaspora community. But it also addresses the global audience.

\section{References:-}

1. Brennan,Timothy. "The National Longing for Farm", ed. HomiBhabha, Nation and Narration. (New York: Routledge, 1990.Print.

2. Bhabha, Homi, K.The Location of Culture. New York: Routledge, 1994. Print.

3. Frantz Fanon. "Introduction", trans. C.L. Markmann, Black Skin, White Masks. New York: Grover Press, 1967.Print.

4. McLeod, John. "Nationalist Representations", Beginning Postcolonialism .New York: Manchester University Press, 2000.Print

5. Mishra,Vijay. "The Law of the Hyphen and the Postcolonial Condition", The Literature of the Indian Diaspora: Theorizing the Diasporic Imaginary. London \& New York: Routledge, 2007.Print.

6. Nityanandam, Indira.The Tale of the Diaspora. New Delhi: Creative Books, 2005.Print.

7. Paranjape, Makarand. "Displaced Relations: Diasporas, Empires, Homelands", In Diaspora: Theories, Histories, Texts. New Delhi: India log Publications Pvt. Ltd., 2001.Print.

8. William Safran, "Diasporas in Modern Societies: Myths of Homeland and Return". Diaspora: Journal of Transnational Studies, Vol. I, No.1, 1997, Print. 